\title{
"The effect of Employment Development Index on economic growth and poverty level in Indonesia"
}

\begin{tabular}{|c|c|}
\hline AUTHORS & $\begin{array}{l}\text { Jamaliah } \\
\text { Muhammad Said (D https://orcid.org/0000-0002-4716-9327 }\end{array}$ \\
\hline ARTICLE INFO & $\begin{array}{l}\text { Jamaliah and Muhammad Said (2017). The effect of Employment Development } \\
\text { Index on economic growth and poverty level in Indonesia. Problems and } \\
\text { Perspectives in Management, 15(2-2), 364-371. doi:10.21511/ppm.15(2- } \\
\text { 2).2017.06 }\end{array}$ \\
\hline DOI & http://dx.doi.org/10.21511/ppm.15(2-2).2017.06 \\
\hline RELEASED ON & Monday, 04 September 2017 \\
\hline RECEIVED ON & Friday, 28 April 2017 \\
\hline ACCEPTED ON & Friday, 26 May 2017 \\
\hline LICENSE & $\begin{array}{l}(c) \text { EY-NG } \\
\text { This work is licensed under a Creative Commons Attribution-NonCommercial } 4.0 \\
\text { International License }\end{array}$ \\
\hline JOURNAL & "Problems and Perspectives in Management" \\
\hline ISSN PRINT & $1727-7051$ \\
\hline ISSN ONLINE & $1810-5467$ \\
\hline PUBLISHER & LLC "Consulting Publishing Company "Business Perspectives" \\
\hline FOUNDER & LLC "Consulting Publishing Company "Business Perspectives" \\
\hline
\end{tabular}

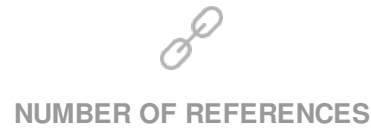

26

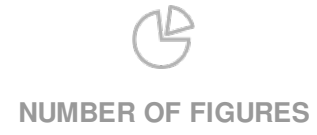

3
NUMBER OF TABLES

2

(C) The author(s) 2023. This publication is an open access article. 


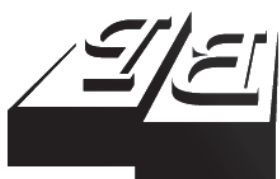

BUSINESS PERSPECTIVES

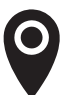

LLC "CPC "Business Perspectives" Hryhorii Skovoroda lane, 10, Sumy, 40022, Ukraine

www.businessperspectives.org

Received on: $28^{\text {th }}$ of April, 2017 Accepted on: $26^{\text {th }}$ of May, 2017

() Jamaliah, Muhammad Said, 2017

Jamaliah, Associate Professor, Development Economic Department, Faculty of Economics and Business, University Tanjungpura, West Kalimantan, Indonesia.

Muhammad Said, Professor, Hariah Economics Department, Faculty of Economics and Business, Syarif Hidayatullah State Islamic University Jakarta, Indonesia.

\section{(ㄷ)(1) $(8)$}

This is an Open Access article, distributed under the terms of the Creative Commons Attribution-NonCommercial 4.0 International license, which permits re-use, distribution, and reproduction, provided the materials aren't used for commercial purposes and the original work is properly cited.
Jamaliah (Indonesia), Muhammad Said (Indonesia)

\section{THE EFFECT OF EMPLOYMENT DEVELOPMENT INDEX ON ECONOMIC GROWTH AND POVERTY LEVEL IN INDONESIA}

\begin{abstract}
This study aims to examine the effect of Employment Development Index (EDI) on economic growth, and the effect of EDI on poverty level and the effect of economic growth on poverty level in Indonesia. This study used descriptive and exploratory analysis with secondary data source, that is, EDI, economic growth, and poverty level in 33 provinces of Indonesia during the period 2012-2013. Linear regression analysis was used to determine the form of force conditions between these three variables. The findings revealed that the effect of EDI on economic growth is insignificant, it was caused by the GDP unable to drive the economic growth and the EDI affects significantly on the poverty level in Indonesia. Then, the effect of economic growth on poverty level is insignificant, which means the economic growth is unable to be the basis for alleviating poverty in Indonesia.
\end{abstract}

\section{Keywords}

\section{JEL Classification}

Employment Development Index, economic growth, poverty

$\mathrm{O} 15$

\section{INTRODUCTION}

Economic development is essentially intended to reduce economic problems. One of the crucial problems to be solved is poverty, a lack of choice and opportunities of the individuals to achieve an optimal exploitation of their potentials to participate in the decision making process affecting their livelihoods and well-being (Arsyad \& Yakamura, 2010).

To prevent them, the theories have been formulated. Trickle down effect means that the society members who live under the economic disadvantage will receive the benefit tricking down from those who are benefited with the growth process. As a matter of fact, it is still unprovoked (Lester, 1980). Althought the Millennium Development Goal (MDG's) has been trying to cut down the extreme poverty up to the level $15 \%$ by 2015 (Bello, 2013), but the fact poverty and unemployment rate is increasing (Banuri, 2013).

Indonesia as a developing country is in the process of change towards a better country. The government continuously tries to reduce poverty and directs the development for just, highly competitive, advanced, and prosperous Indonesian people. One way to achieve this aim is through Human Development Index (Siburian, 2013).

The high number of people who live under the poverty line drives the government to increase the Employment Development Index (EDI) as an indicator to evaluate the level of welfare in economy, education and health 
(Todaro, 2003, p. 21). Some policies and programs were formulated by the government to reduce the poverty level such as anti-poverty policy, cash transfer supporting the IMPRES Village, business credit for farmers, National Program for Community Empowerment (PNPM), the Direct Aid of Mandiri (BLSM). However, these programs have shown their minimum impact, which is indicated by the poverty rate at $11.66 \%$ by 2012 , and the highest percentage of poor people is in Papua province, 30.66 percent (BPS, 2014).

The poverty rate is influenced by many factors, which, among others, are economic growth and Employment Development Index (EDI) (Lin, 2003; Ravalion, 2005; Bourguignon, 2004; War, 2006; Dewento \& Suriadi, 2014). Indonesia's economic growth in the period 2011-2013 shows the EDI constituting value, which describes the successful conditions of development and employment. EDI is regarded as the fundamental sector: workforce planning, population and labor, creation of employment opportunities, training and labor competence, labor productivity, industrial relations, working conditions, wages and welfare, labor social security. The high value of HDI will reduce poverty (Labor Ministry, 2014).

Value of national EDI within the period of 3 (three) last years has increased by 6.39 from 49.92 in 2011 to 56.31 in 2013. The results of EDI in respective Indonesian provinces have different success levels, which are caused by the district government's priority, human resources (HR) availability, infrastructure and high support from the central government and other institutions.

Nationally, the EDI of the provinces is at the level of lower middle class. Only two provinces encounter the decrease, West Kalimantan and West Nusa Tenggara. The West Kalimantan witnessed a decrease from the lower middle status with value of 50.08 (29th ranking) in 2012 to a low status with value of 47.25 (33rd ranking) in 2013. Meanwhile, level of lower middle class West Nusa Tenggara decreased from 51.82 (24th ranking) in 2012 to 49.49 (31st ranking) in 2013 (Manpower Planning Center, 2012). Hence, this study traces the effect of EDI on economic and poverty growth in Indonesia. It aims to examine and to analyze the effect of Employment Development Index (EDI) on economic growth and poverty rate in Indonesia.

\section{LITERATURE REVIEW}

\subsection{Economic development and growth theories}

Development is an attempt to enhance the growth of both the national Gross D omestic Product (GDP) and local GDP. The GDP is one of the indicators, which reflect national prosperity level apart from production and emplo y ment. Triwidodo (2006) adds that development covers changes at the social structure, att itudes of society, as well as national institutions $w$ ithout prejudice to the initial objective, economic growth, handling the income gap and expansion of employment opportunities. The success of the economic development also depends on people's ability to fulfill their basic needs, to increase the sense of self-esteem and increase a freedom of choice (Arsyad, 2010).

Khuznet defined economic growth as long-term increase in country's ability to provide more and more kinds of economic goods and services to its citizens in accordance with the technological progress and the necessity to adjust institution and ideology (Jhingan, 2008; Todaro, 2003; Sukirno, 2004, p. 56; Mankiw, 2003, p. 18).

\subsection{Poverty}

Poverty means life under the minimum living standards set by the basic need for food that makes people work and live healthily in accordance with the needs for rice and nutrition (Sajogyo in Widodo, 2006). Jhingan (2002, p. 35) presented three main characteristics of developing countries which, cause and impact the poverty. First, infrastructure and educational facilities are inadequate resulting in a large number of the illiterate and unskilled people. Second, the bad proposition of health and consumption patterns makes only minority populations become productive in their labor. Third, the populations concentrate in the agricultural and mining sectors with old and out-of- 


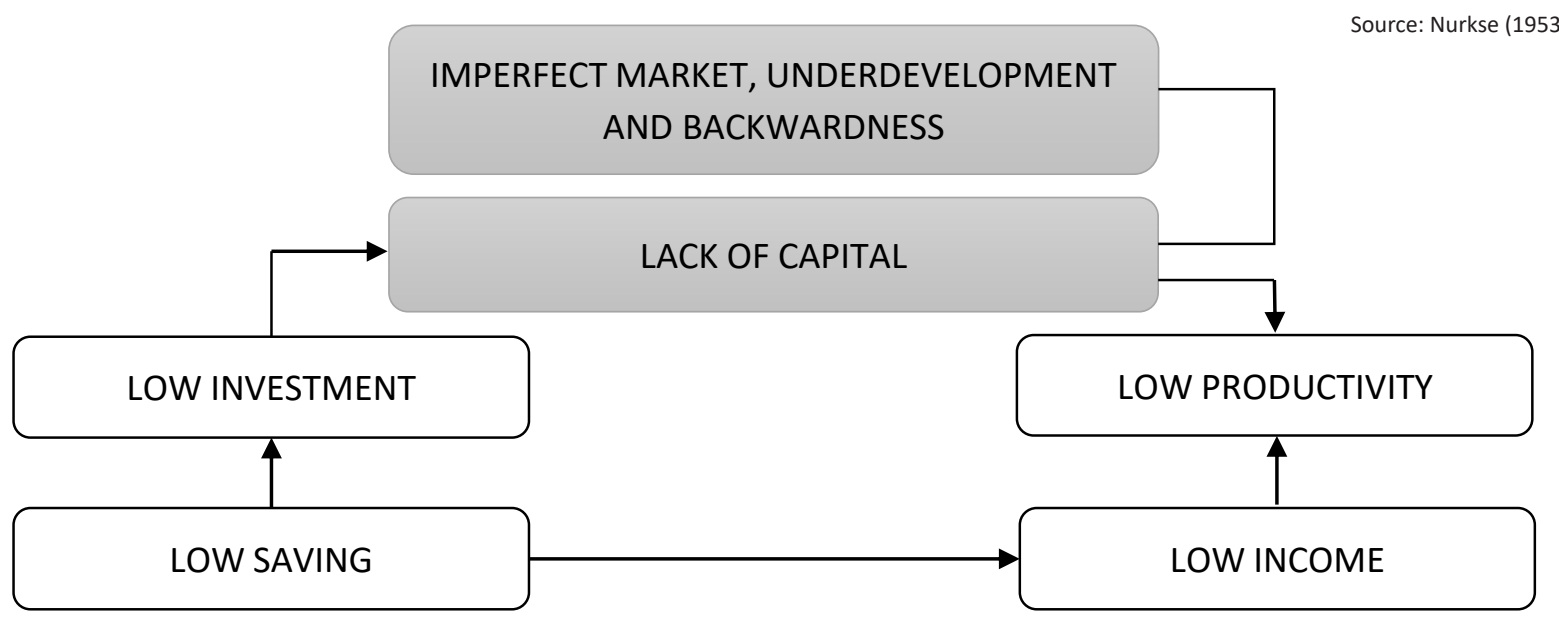

Figure 1. Nurkse's Vicious Circle

date production methods. Apart from that, Badruddin (2012) added that poverty is caused by the inequality of resource ownership patterns. Poor people have only a limited number and low quality of resources. Poverty is also caused by the different quality of human resources. Low quality of human resource leads to low productivity. Low quality of human resources is due to the lack of education, less fortune, discrimination or descent, and different opportunity of accessing to capital (Triwidodo, 2006). The limited employment opportunities, which are caused by educational level or lower skill results in limited job opportunities and poverty condition (Triwidodo, 2006, p. 297; Todaro, 2008; Sen, 1995; Bellinger, 2007; Fies de Verner, 2004).

Nurkse's Vicious Cycle describes the vicious cycle which, substantially derives the poverty level, where total productivity in underdeveloped countries is low, which is reflected in the low real income. The low income level structurally results in low level of demand and low investment, which leads to less capital and low productivity. The following figure shows the vicious cycle by Nukse.

\subsection{Employment Development Index (EDI)}

There are many indicators used to measure EDI, but generally the main indicators are: 1) manpower planning; 2) population and manpower; 3) job opportunities; 4) training and labor competence; 5) productivity of $\mathrm{m}$ a npower; 6) industrial relation; 7) working conditions; 8) remuneration and welfare of workers; 9) social security of manpower (Department of Labor, 2013). Employment issues are quite spacious. The narrow employment opportunities lead to the increased unemployment rate, low income level and low purchasing power increasing the poverty rate.

\subsection{The relation of EDI toward economic growth}

Employment Development Index consists of employment indicators, which job opportunities, unemployment, labor productivity, wages and others. Employment and decent work should be fought by the government for the welfare of the people. Workers' eligibility is expected to reach $75 \%$ of the number of worker s (Labor Ministry, 2014). Meanwhile, the unemp loyment rate describes the amount of labor force seeking the job and the amount is expected to be smaller, $3 \%$ of the total labor force.

Labor productivity is the average value of goods and services produced by workers. The best measure of the successful HDI is IDR100 million/labor and the worst is IDR 5 million/labor, and wages can be seen from the determination of the minimum wage in respective provinces.

EDI will have an influence on economic growth. High quality of Human Development Index impacts high productivity and high output or Gross Domestic Product (GDP). Nizar et al. (2013) found the significant results between EDI, government investment and labor on economic growth. 
Table 1. Operational variable compensation

\begin{tabular}{|c|c|c|}
\hline Variable & Indicator & Measurement \\
\hline $\begin{array}{l}\text { Employment Development Index as the } \\
\text { independent variable }(X)\end{array}$ & $\begin{array}{l}\text { The amount of Employment Development Index } \\
\text { (EDI) in Indonesia }\end{array}$ & Percentage \\
\hline Economic growth as dependent variable $\left(Y_{1}\right)$ & The amount of economic growth in Indonesia & Percentage \\
\hline Poverty rate as dependent variable $\left(Y_{2}\right)$ & The number of poor people in Indonesia & Percentage \\
\hline
\end{tabular}

Meanwhile, the high wages will influence the productivity and, in turn, will increase the economic growth (Sumardin et al., 2004). According to Lewis (1993), labor migration from traditional sector to modern sector caused the increase of economic growth.

\subsection{The effect of EDI on poverty}

Various studies find out the factors affecting poverty. Serendipity (2013) asserted that government expenses and open unemployment rate have a significant effect on poverty level. The unemployment rate has a positive effect on poverty. The smaller the unemployment rate, the smaller is the poverty rate. The high unemployment rate affects the economic downturn (Ridho, 2010; Sukmaraga, 2011). Gakuru and Naomi (2011) added the lack of job opportunities, commodity prices, the lack of land, low productivity, and low industrial development as factors contributing to poverty.

\subsection{The effect of economic growth on poverty}

There are some studies, which found the negative significant relationship between economic growth and poverty rate (Nizar, et al., 2013; Septyana \& Yuliarmi, 2013; Arius, 2012; Chen \& Revallion, 2011; Noudhton, 2012; Tadaro, 2006). Moreover, Barros and Mendonca (1997) analyzed the relationship between economic growth, inequality and poverty in Brazil. They found that economic growth can reduce poverty, but inequality is more effective in reducing poverty.

\section{RESEARCH METHOD}

\subsection{Data and variables}

This research used panel data combining time series data for the period 2012-2013 and cross section data for 33 provinces. The secondary data derived from various publications grouped by the Central Bureau of Statistics including economic growth, percentage of the poor and Human Development Index (HDI) in Indonesia.

The research variable is the object on which the research focused its analysis (Rianse, 2008). The variable of study was developed further with each variable, as it is shown in Table 1.

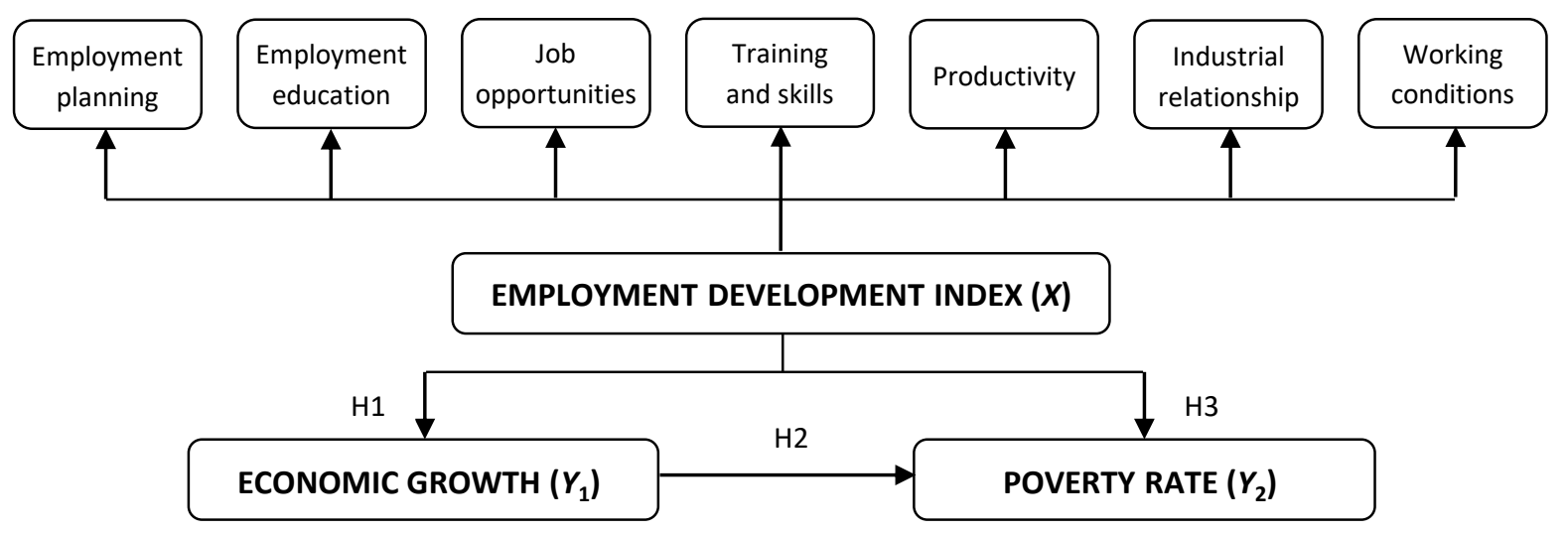

Figure 2. Conceptual framework 
Table 2. The Result of t-test Partial between EDI toward Economic Growth and Poverty in Border Region

Source: processed data.

\begin{tabular}{|c|c|c|c|c|}
\hline Variable & t-statistic & Prob & Beta & Information \\
\hline EDI toward economic growth & -1.645 & 0.105 & -0.201 & Insignificant \\
\hline Economic growth toward poverty rate & 1.761 & 0.083 & 0.215 & Insignificant \\
\hline EDI on poverty rate & -4012 & 0,000 & -0.448 & Significant \\
\hline
\end{tabular}

\subsection{Operational definition of variables}

Employment Development Index

Employment Development Index is a value which describes the successful conditions of employment development in a region measured by percentage.

\section{Economic growth}

Economic growth is the added-value or the output of goods and services produced in an economy measured by percentage.

\section{Poverty}

Poverty is the number of people living under the poverty line becoming the basis to calculate the number of poor people based on two criteria: the consumption expenditure per capita per month equivalent to 2100 calories per capita per day and the minimum requirement value of food commodities not measured in percentage.

\section{Analytical tools}

Multiple regressions with panel data were analyzed using the computer program SPSS 16 and the formula asserted by Widarjono $(2009$, p. 59$)$ as follows:

$$
Y_{1}=\beta_{0}+\beta_{1} \cdot X_{1}+\ldots+\text { Error }
$$

where $Y_{1}-$ level of poverty;

$B_{0}$ - intercept regression coefficient $\beta$;

$X$ - Employment Development Index (EDI).

Hypothesis testing in this study was conducted using linear regression at a confidence level of 95\% or $\alpha=5 \%$.

The conceptual framework of this research can be seen at Figure 2.

\section{FINDINGS AND DISCUSSION}

\subsection{Partial test}

The results of the study can be analyzed based on the results of SPSS data processing, which is to determine the effect between Employment Development Index (EDI) and Indonesian poverty rate as a dependent variable $(Y)$. The result of each variable is presented in Table 2 .

\subsection{The effect of EDI on economic growth in Indonesia}

Table 2 shows that $\mathrm{t}$-test value is -1.645 with significance value of 0.105 . It indicates an insignificant relationship between EDI and economic growth. A negative correlation indicates that the higher the EDI, the lower the economic growth. Because the effect is very small, it becomes insignificant. The result describes that EDI does not affect directly the economic growth or there are another variables outside the model that affect the rate of economic growth. The insignificant influence of EDI on economic growth is possible, because there are many indicators so cumulatively it has indirect an effect.

EDI is generally measured using several main indicators such as workforce planning, population and employment, job opportunities, training and competence/skills, labor productivity, industrial relations and working conditions. The finding of this study confirms the conclusions by Al-Habees Mahmoud A and M Abu Rumman (2012) who state that the unemployment insignificantly affects the economic growth. 


\subsection{The effect of EDI on poverty in Indonesia}

The result of significant test (t-test) for the variable $\mathrm{X}$ (EDI) is -4.012 lying on the acceptance of H0. It means that the EDI significantly affects the poverty rate. The higher the EDI, the lower the poverty rate.

The results show that the EDI has an important role in reducing poverty rate, which is the EDI that describes the level of success in employment development, which indicates, among others: the decrease unemployment rate and slaves, and number of increased labor productivity, work incomes, labor supervision, labor status and, in turn, will increase the welfare of people. The EDI describes not only the success of quantity aspects, but also the success in achieving labor quality. The EDI can be affected by the priority of government development, the education of human resource, health, the support system and the investment in labor.

According to the observations, the effect of EDI $(\mathrm{X})$ on poverty $(\mathrm{Y})$ in each province in Indonesia shows the varying patterns.

Figure 3 shows that EDI generally increases and then followed with the decline in the number of poor people in Indonesia although the declining percentage of poverty rate does not decrease drastically. According to the data, the average EDI escalation affected the decrease of poverty rate in Indonesia. By 2011, the EDI was $49.92 \%$, $54.15 \%$ in 2012 and 56.31 in 2013. This achievement significantly affects the decrease of pover- ty rate in Indonesia, which, in 2011, was $12.49 \%$, then $11.66 \%$ in 2012 , and $11.47 \%$ in 2013 . Overall, there is an increase of index value in 2012-2013 for each province. The province of Jakarta has the highest index, from 61.90 to 64.83 , but the level of status has not changed, still in the lower middle. Meanwhile, there are several provinces witnessing a decrease of index value of EDI, which are West Nusa Tenggara with the value from 51.82 (2012) to 49.49 (2013) and West Kalimantan with the value from 51.08 (2012) to 47.25 (2013) so that their status levels also decrease from the lower middle to low. This finding supports Barika (2013), Rosya (2010) and Sukmaraga (2011) that the government expenditures and open unemployment rate significantly affect the increase of poverty rate. Gekuru and Naomi (2011) also say that factors affecting the poverty are lack of job opportunities, lack of land, lower productivity and industry development.

\subsection{The effect of economic growth on poverty rate in Indonesia}

According to the statistic calculation in Table 2, there is influence of economic growth on poverty rate in Indonesia (sig value $0.083>0.05$ ). The high economic growth is supposed to reduce the poverty, but as the effect is very low, it becomes insignificant.

The insignificant effect of economic growth on poverty rate is because the economic growth is followed by the decreasing poverty rate. The small increase in economic growth is still unable to increase the community's income or social welfare. The economic growth will possibly not benefit the

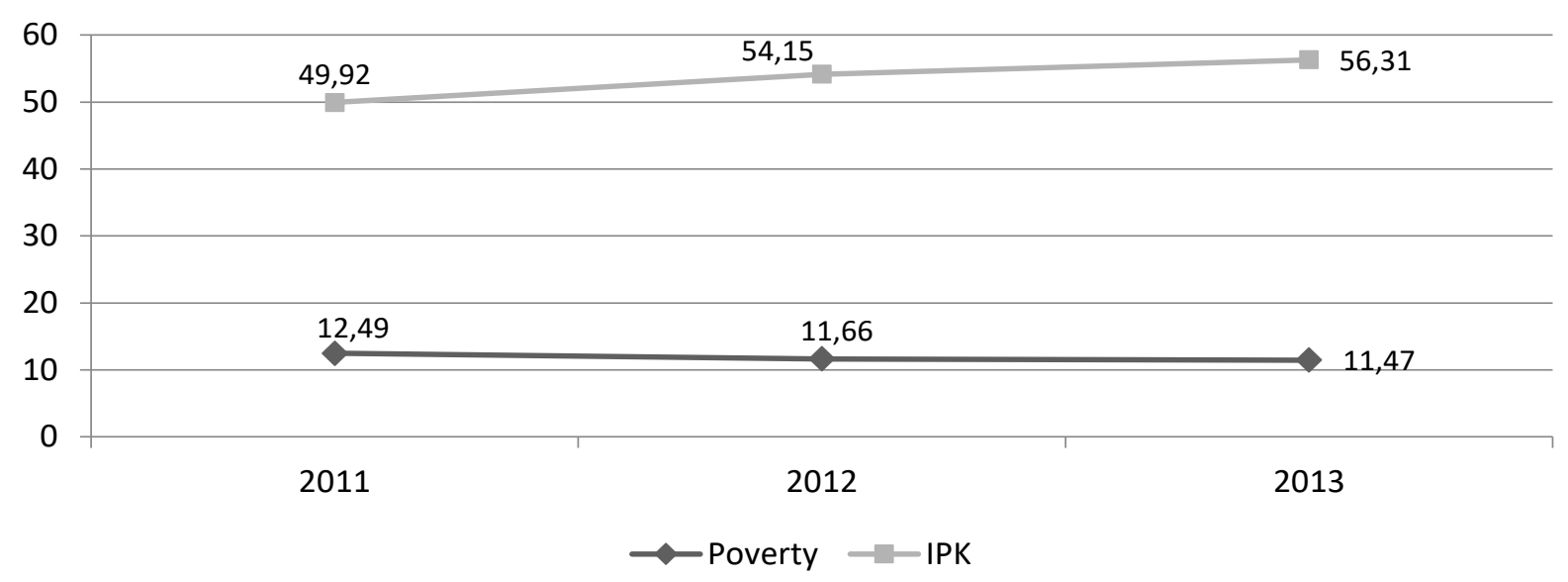

Figure 3. EDI and poverty in province in Indonesia during 2011-2013 
society in the low strata so it can indirectly increase the poverty of population. Besides, the poverty issues considered as multi-dimension issues (Sen, 1995).

This result contradicts to that by Arius Jonaidi (2012) who showed that the economic growth is negatively correlated with poverty rate in Indonesia. It means that the higher the economic growth, the lower poverty rate in Indonesia. Dollar and Kraay in Houdhton (2012) concluded that the policy concerning the average revenue increase is an essential factor the for successful strategy of reducing the poverty including improvement in education, health sector, infrastructure, etc. This finding confirms the World Bank statement (1990, 2000), Todaro (2006), and Houghton (2012). Meanwhile, it contradicts to Skare and Romina (2016) that in several cases in developing countries like India and China, the rate of economic growth does not significantly reduce poverty. Also, Mustamin (2015) and Pendi et. al. (2014) state that economic growth insignificantly affects the poverty rate.

\section{CONCLUSION}

The results of hypothesis testing conclude that, first, the effect of EDI on economic growth is insignificant. The conditions of employment, productivity, social security, work environment, and other showed the lower quality that indirectly and significantly cannot boost the economic growth yet. Second, EDI significantly affects the poverty rate. The significant relationship between GDP and poverty was consistent with the EDI and the decrease in poverty rate. Third, the effect of economic growth on poverty is not significant which means that the economic growth cannot become the basis for alleviating poverty. Generally, economic growth is driven by consumption rather than investment. Besides, poverty issue is determined not only by economy, but also multidimensional aspects.

\section{RECOMMENDATIONS}

The government needs to focus more on the EDI and continuously improve the education, work skills, unemployment, productivity, wages and industrial relations. The high quality of human resources can drive economic growth and directly impact the reduction of poverty. Qualified economic growth should also be improved through other interrelated factors such as private and public investment, infrastructure, education and health, in addition to manpower development.

\section{ACKNOWLEDGEMENT}

The authors wish to thank Muhammad Arsyad, Ph.D. (Hasanuddin University) for his valuable comments on earlier drafts of this paper and providing us some references on the poverty and development issues.

\section{REFERENCES}

1. Al-Habees, A., \& Abu, M. M. (2012). The Relationship Between Unemployment and Economic Growth in Jordan from Arab Countries. World applied sciences journal, 18(5), 673-680. https:// doi.org/10.5829/idosi. wasj.2012.18.05.16712
2. Arsyad, M., \& Yoshio, K. (2010). Reducing Poverty of Cocoa Smallholders in Indonesia: Is Agricultural Economic Activity Still the Pioneer? Economics and Finance in Indonesia, 58(2), 217-238.

3. Banuri, T. (2013). The future of economy. Development,
5(2), 145-148. https://doi. org/10.1057/dev.2013.37

4. Bello, W. (2013). Post 2015 development assessment: proposed goals and indicators. Development, 56(1), 93-102. https://doi.org/10.1057/ dev.2013.10 
5. Bourguignon, F. (2004). The Poverty - Growth Triangle Inequality. Washington. World Bank.

6. Fiess, N. M., \& Dorte, V. (2004). The Dynamics of Poverty and Its Determinants: The case of Northeast Brazil and its States. World Bank Policy Research Working Paper, 3259.

7. Herry, F. (2013). Effect of Education, Health on Productivity and Poverty rates in West Kalimantan Province. Thesis Graduate Program Faculty of Economics, UNTAN.

8. Jonaidi, A. (2012). Analysis of the Economic Growth and Poverty in Indonesia. Journal of Economic Studies, 1(1), 212-317.

9. The Ministry of Labor. (2014). The Employment Development Index (CPI) in 2013, Jakarta.

10. Lin, B. Q. (2003). Economic growth and income inequality and poverty reluction in People's Republic of China. The Asian Development Review, 20, 105-124.

11. Lowry, A. (2012). The foverty falls despite global slump, report finds. In Bello, Walden. (2013). Post 2015 development assessment: proposed goals and indicators. Development, 56(1), 93-102.
12. Mega, S., \& Ni, N. Y. (2013). Factors Affecting Poverty Level, in the province of Bali. E-Journal of Development Economics, 2(10), 441-448.

13. Mustamin, S., Salim, M. and Sri (2015). Influence of Macroeconomic Variables Against Poverty In the city of Makassar, South Sulawesi Province. Analysis Journal, 4(2), 165-173.

14. Nizar, Chairul Abubakar Hamza, \& Sofyan, Syahnur. (2013). Effect of Investment and Labor Against Economic Growth And Relation Against Poverty Level in Indonesia. Journal of Economic Sciences, 1(2).

15. Prasetyo, B., \& Lina, M. J. (2005). Quantitative Research Methods: Theory and Applications. Jakarta: PT Raja Grafindo Persada.

16. Ravallion, D. G. (2006). Inequality is Bad For The Poor. World bank policy research working paper, 3677.

17. Rianse, U., \& Abdi. (2008). The methodology of Social and Economic Research: Theory and Applications. Bandung: Alfabeta.

18. Rosya, M., Faruh, Ridho. (2010). Unemployment and Urban Development (Case Study of Palembang). Journal of Urban and Regional Planning, 21(1), 55-68.
19. Sen, A. (1995). A Sosiological Approach to the Measurement of Poverty: A Reply to Professor Fr Townsend. Ouford Economic Papers, 3, 669-676.

20. Siburian, Vera, Heryani. (2013). Analysis of Labor Absorption in the Small and Medium Industries, Diponegoro. Journal of Economics, 1(4), 2537-3814.

21. Skare, M., \& Romina, P. D. (2016). Proverty and Economics Growth. Development of Economy and Economics, 22(1), 156-175.

22. Sumardin et all., (2004). Analysis of Relationship Wage Rate High on Productivity in Indonesia. Journal of Economic MEPA Usud, 06.46 .

23. Suryahadi, A. D., \& Sumarto, A. (2006). Economic Poverty Reduction and Growth In Indonesia: The Effects of Location And Pectoral Component Of Growth. Working Paper.

24. Todaro, M. P. (2008). Economic Development (Ninth Edition). Jakarta: Erland.

25. Tri, W. (2006). Development Planning: Computer Applications regional autonomy. Yogyakarta: UPPSTIM YKPN.

26. Warr, P. (2006). Poverty and Growth in Southest Asia ASEAN. Economic Bulletin, 23, 279-302. 